\title{
The Effect of Chlorine and Heat on Spores of Clostridium bifermentans
}

\author{
By W. M. WAITES, N. R. KING AND CATHERINE E. BAYLISS \\ Agricultural Research Council, Food Research Institute, Colney Lane, Norwich NR4 7 UA
}

(Received 5 May 1977)

\section{INTRODUCTION}

Waites et al. (1976) showed that spores of Clostridium bifermentans, which had lost peripheral phase brightness after being killed by incubation with high concentrations of hydrogen peroxide, had also lost most of their cortex, calcium and dipicolinic acid (DPA). Addition of monovalent cations to such spores resulted in a fall in turbidity, loss of the remaining phase brightness and swelling of the protoplasts although these changes could be prevented by the presence of calcium ions. Since monovalent cations are required for the germination of untreated spores and since the loss of calcium, DPA and cortex together with protoplast swelling also occur during germination (for a review see Gould, 1969), we suggested that replacing the calcium within the spore by monovalent cations could be one of the initiating events in germination. It is possible, however, that the changes in spores treated with peroxide might be specific to the action of the peroxide. We have therefore investigated whether other agents including chlorine and heat can produce spores which undergo similar changes. This communication reports the effect of these agents in combination.

\section{METHODS}

Organism, spore preparation and maintenance of cultures. The strain of Clostridium bifermentans used and the preparation and storage of spores were as described previously (Waites \& Wyatt, 197I) except that spores were produced on a trypticase agar as described by Bayliss \& Waites (1976). The organism was maintained in the reinforced clostridial medium of Hirsch \& Grinsted (I954).

Treatment of spores with chlorine. Spores (about $0.7 \mathrm{mg}$ dry $\mathrm{wt}^{-1}$ ) were added to $250 \mathrm{~mm}$-sodium phosphate buffer $\mathrm{pH} 7.0$ containing sodium hypochlorite $(\mathrm{BDH})$ to give $200 \mu \mathrm{g}$ free chlorine $\mathrm{ml}^{-1}$, incubated for $10 \mathrm{~min}$ at $0^{\circ} \mathrm{C}$, and then washed with glass-distilled water as described previously (Wyatt \& Waites, I973). Free chlorine was measured by the Palin method (Palin, 1957) with $N, N$-diethyl-p-phenylene diamine (DPD) tablets $(\mathrm{BDH})$ and using the extinction coefficient at $553 \mathrm{~nm}$.

Heat treatment of spores. Spores treated with $200 \mu \mathrm{g}$ free chlorine $\mathrm{ml}^{-1}$ were heated at $80{ }^{\circ} \mathrm{C}$ for $0,10,20$, $30,45,60$ or $90 \mathrm{~min}$ at about $7 \mathrm{mg}$ dry $\mathrm{wt} \mathrm{ml}^{-1}$ in glass-distilled water in screw-capped glass bottles before centrifuging, resuspending in glass-distilled water and storing at $I^{\circ} \mathrm{C}$.

Measurement of dipicolinic acid. This was measured in the supernatants from heated spores both spectrophotometrically at $27 \mathrm{I} \mathrm{nm}$ and colorimetrically by the method of Janssen, Lund \& Anderson (1958) using a solution of DPA (Koch-Light) as a standard. The same results were obtained by either method.

Spore dry weight. Dry weights were estimated spectrophotometrically; $E_{600}$ values were converted to spore dry weight using a standard calibration curve.

Measurement of decrease in turbidity and loss of phase brightness. Spore suspensions (about $40 \mu \mathrm{g}$ dry wt $\mathrm{ml}^{-1}$ ) were incubated at $37^{\circ} \mathrm{C}$ in $2.5 \mathrm{ml}$ glass-distilled water in a cuvette of $\mathrm{I} \mathrm{cm}$ light path. Sodium chloride, sodium phosphate buffer $\mathrm{pH} 8.0$ or Tris $/ \mathrm{HCl}$ buffer $\mathrm{pH} 8.0(0.3 \mathrm{ml})$ were added to a final concentration of $100 \mathrm{~mm}$ and the decrease in turbidity at $600 \mathrm{~nm}$ was recorded spectrophotometrically. Loss of central or peripheral brightness was measured under similar conditions by counting 100 spores using a phase contrast microscope.

Preparation of samples for electron microscopy. For electron microscopy, spore suspensions were fixed and embedded as described previously (Waites, Wyatt \& Arthur, 1972). 

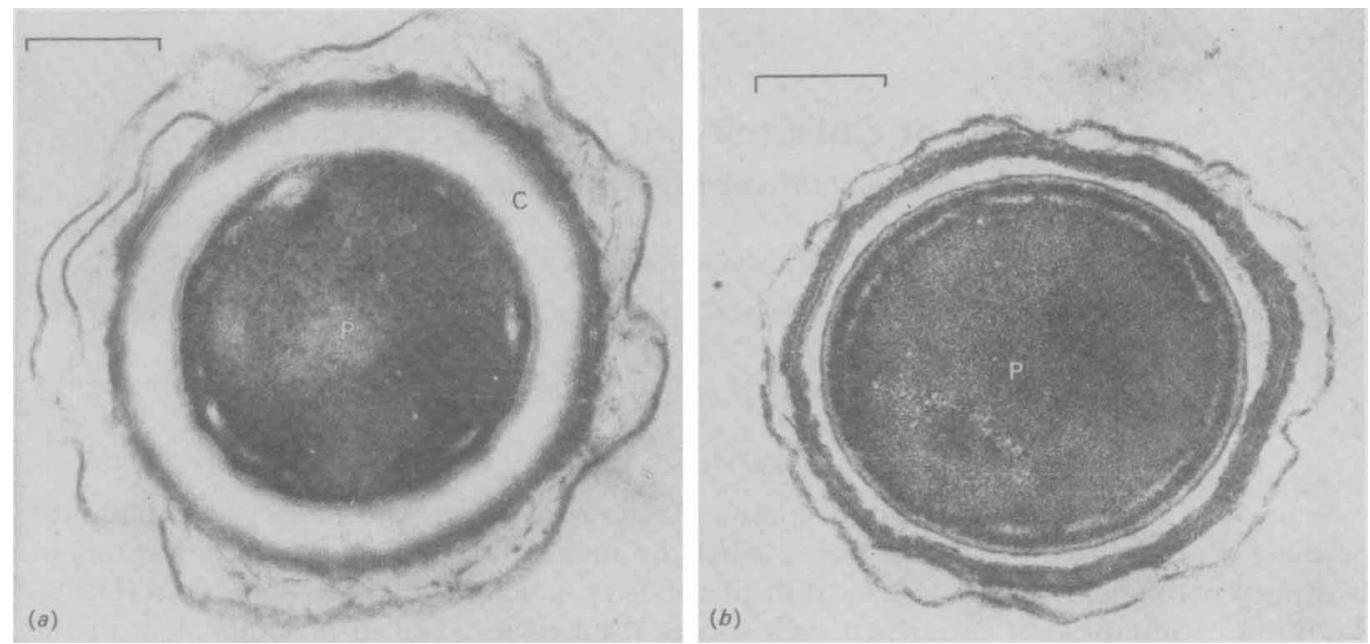

Fig. I. Effect of chlorine and heat on the ultrastructure of spores of Clostridium bifermentans. Electron micrographs show thin sections of spores $(a)$ treated with $200 \mu \mathrm{g}$ free chlorine $\mathrm{ml}^{-1},(b)$ treated spore heated at $80^{\circ} \mathrm{C}$ for $30 \mathrm{~min}$. C, cortex; P, protoplast. Bar markers represent $0.25 \mu \mathrm{m}$.

\section{RESULTS}

Spores of Clostridium bifermentans killed by $200 \mu \mathrm{g}$ free chlorine $\mathrm{ml}^{-1}$ appeared bright on examination by phase contrast microscopy, and similar to untreated spores on examination by electron microscopy (Fig. I $a$ ). Addition of Ioo mM-sodium phosphate or Tris/ $\mathrm{HCl}$ buffers at $\mathrm{pH} 8.0$ or $100 \mathrm{~mm}$-sodium chloride resulted in less than a $10 \%$ fall in the turbidity of the spore suspension. On heating for 10 min or longer at $80{ }^{\circ} \mathrm{C}$, at least $80 \%$ of these spores lost phase brightness from their periphery and appeared to be identical to those treated with high concentrations of hydrogen peroxide (Waites et al., 1976). When chlorine-treated spores were heated for $10 \mathrm{~min}$, about $50 \%$ of the DPA of the spore was lost into the supernatant; in most experiments little extra was lost on further heating, the maximum observed being a further $10 \%$ after another $50 \mathrm{~min}$. Electron microscope examination of thin sections of spores that had been heated for 30 min showed that the majority had lost much of their cortex and had swollen protoplasts (Fig. I $b$ ). On adding Ioo mMsodium phosphate or Tris/ $\mathrm{HCl}$ buffers at $\mathrm{pH} 8.0$ or $100 \mathrm{~mm}$-sodium chloride, the heated spores lost their remaining phase brightness and also 80,63 or $56 \%$ of their initial turbidity, respectively, within Io min. As with peroxide-treated spores (Waites et al., 1976), the presence of $5 \mathrm{mM}-\mathrm{CaCl}_{2}$ prevented the heated spores losing central phase brightness and also turbidity on addition of Tris/ $\mathrm{HCl}$ buffer.

\section{DISCUSSION}

We have shown that treatment of spores of Clostridium bifermentans with chlorine and heat produce similar changes to those produced by peroxide. However, although the spores treated with peroxide had lost all their cortex, the protoplasts remained much more contracted than those in the present study, probably because of the low $\mathrm{pH}$ of the treatment with peroxide (Hitchins \& Gould, I964).

There are obvious similarities between heat activation of spores and the changes produced in the present work by heating chlorine-treated spores. After heat activation, spores germinate more rapidly and with a greater number of germinants (Keynan \& Evenchik, 1969) and during heat activation up to $10 \%$ of the spore DPA may be lost (Keynan, Murrell \& Halvorson, I96I). We found that DPA is also lost on heating. The ability to undergo germination-like changes on adding sodium chloride alone could be considered an 
extension of the relaxation of germination requirements since amino acids and sodium ions are required for germination of untreated spores of this strain (Waites \& Wyatt, I97I). Spores damaged by chlorine lose heat resistance (Dye \& Mead, 1972; Wyatt \& Waites, 1975) and, on mild heating, lose spore constituents such as DPA (Alderton \& Halbrook, I97I; Dye \& Mead, I972). However, structural changes accompanying the loss of these constituents and the subsequent effects of cations were not examined, although treatment of spores of Bacillus cereus with higher concentrations of chlorine degrades the spore coat and causes eventual loss of calcium ions and DPA (Kulikovsky, Pankratz \& Sadoff, 1975). Since there is no evidence that heating at $80{ }^{\circ} \mathrm{C}$ degrades the cortex of untreated spores, the chlorine treatment in our study must alter the cortex and make it susceptible to such heating.

Although the heated spores in our study retained much of their phase brightness, they had lost most of their cortex and the protoplast had expanded. Under phase contrast their appearance was similar to that of the heat-inactivated germinated spores of Hashimoto, Frieben \& Conti (1972), but whether such spores had also lost cortical material and had expanded protoplasts is unknown. The remaining brightness under phase contrast is presumably due to the physical characteristics of the partially swollen protoplast. As DPA was lost during expansion of the protoplast, it would be of interest to determine if any protoplast swelling occurs when DPA is lost during activation of untreated spores.

We are grateful to Dr J. L. Peel for useful discussions and Miss L. J. Nockolds for skilled technical assistance.

\section{REFERENCES}

Alderton, G. \& Halbrook, W. U. (197I). Action of chlorine on bacterial spores. Bacteriological Proceedings, p. 12.

Bayliss, C. E. \& Waites, W. M. (I976). The effect of hydrogen peroxide on spores of Clostridium bifermentans. Journal of General Microbiology 96, 4OI-407.

DYE, M. \& MEAD, G. C. (1972). The effect of chlorine on the viability of clostridial spores. Journal of Food Technology 7, 173-181.

Gould, G. W. (1969). Germination. In The Bacterial Spore. Edited by G.W. Gould and A. Hurst. London: Academic Press.

Hashimoto, T., Frieben, W. R. \& Conti, S. F. (I972). Kinetics of germination of heat-injured Bacillus cereus spores. In Spores V, pp. 409-4I5. Edited by H. O. Halvorson, R. Hanson and L. L. Campbell. Washington, D. C.: American Society for Microbiology.

Hirsch, A. \& Grinsted, E. (1954). Methods for the growth and enumeration of anaerobic sporeformers from cheese, with observations on the effect of nisin. Journal of Dairy Research 21, IOI-IIO.

Hitchins, A. D. \& Gould, G. W. (1964). Release of cores from bacterial spores by mechanical breakage in acidic media. Nature, London 203, 895-896.

Janssen, F. W., Lund, A. J. \& Anderson, L. E. (1958). Colorimetric assay for dipicolinic acid in bacterial spores. Science, 127, 26-27.

Keynan, A. \& EvenchiK, Z. (1969). Activation. In The Bacterial Spore. Edited by G. W. Gould and A. Hurst. London: Academic Press.

Keynan, A., Murrell, W. G. \& Halvorson, H. O. (I961). Dipicolinic acid content, heat-activation and the concept of dormancy in the bacterial endospore. Nature, London 192, I 2 I I-I 212.

Kulikovsky, A., Pankratz, H. S. \& Sadoff, H. L. (1975). Ultrastructural and chemical changes in spores of Bacillus cereus after action of disinfectants. Journal of Applied Bacteriology 38, 39-46.

Palin, A. T. (1957). The determination of free and combined chlorine in water by the use of diethylp-phenylene diamine. Journal of the American Water Works Association 49, 873-880.

Waites, W. M. \& WyatT, L. R. (197I). Germination of spores of Clostridium bifermentans by certain amino acids, lactate and pyruvate in the presence of sodium or potassium ions. Journal of General Microbiology 67, 2 15-222.

Waites, W. M., WyatT, L. R. \& Arthur, B. (1972). Effect of alkali treatment on the germination and morphology of spores of Clostridium bifermentans. In Spores $V$, pp. 430-436. Edited by H. O. Halvorson, R. Hanson and L. L. Campbell. Washington, D.C.: American Society for Microbiology.

Waites, W. M., Wyatt, L. R., King, N. R. \& BAYliss, C. E. (1976). Changes in spores of Clostridium bifermentans caused by treatment with hydrogen peroxide and cations. Journal of General Microbiology 93, 388-396.

WyatT, L. R. \& Waites, W. M. (1973). The effect of hypochlorite on the germination of spores of Clostridium bifermentans. Journal of General Microbiology 78, 383-385.

WyATT, L. R. \& WaItes, W. M. (I975). The effect of chlorine on spores of Clostridium bifermentans, Bacillus subtilis and Bacillus cereus. Journal of General Microbiology 89, 337-344. 